\title{
PENGARUH BUDAYA ORGANISASI TERHADAP SEMANGAT KERJA DENGAN KEPUASAN KERJA SEBAGAI VARIABEL MEDIASI (STUDI PADA PERUM LEMBAGA PENYELENGGARAAN PELAYANAN NAVIGASI PENERBANGAN INDONESIA CABANG TARAKAN)
}

\author{
THE EFFECT OF ORGANIZATIONAL CULTURE ON THE EMPLOYEE \\ MORALE WITH WORK SATISFACTION AS MEDIATION VARIABLES \\ (STUDY ON PUBLIC COMPANY OF THE INDONESIAN TARAKAN \\ NAVIGATION SERVICE PROVISIONING AGENCY)
}

\author{
Teguh Imam Prijatna ${ }^{1)}$, Widyastuti Cahyaningrum ${ }^{2)}$ \\ (Universitas Borneo Tarakan)
}

\begin{abstract}
Abstrak: Penelitian ini bertujuan untuk menguji pengaruh budaya organisasi terhadap semangat kerja, pengaruh budaya organisasi terhadap kepuasan kerja, pengaruh kepuasan kerja terhadap semangat kerja, dan budaya organisasi terhadap semangat kerja dengan kepuasan kerja sebagai variabel mediasi karyawan PERUM Lembaga Penyelenggaraan Pelayanan Navigasi Penerbangan Indonesia Cabang Tarakan. Pada penelitian ini menggunakan pendekatan kuantitatif dengan metode eksplanatori, pengambilan sampel dilakukan dengan teknik penentuan sampel kuota dimana dari keseluruhan populasi, sampel diambil sesuai kehendak peneliti dengan memenuhi kriteria yang ditentukan yaitu sebanyak 50 karyawan PERUM Lembaga Penyelenggaraan Pelayanan Navigasi Penerbangan Indonesia Cabang Tarakan dijadikan sebagai sampel. Metode analisis menggunakan alat analisis dengan bantuan program SPSS versi 18.0. Hasil penelitian ini menunjukkan bahwa budaya organisasi berpengaruh positif signifikan terhadap semangat kerja karyawan, budaya organisasi berpengaruh positif signifikan terhadap kepuasan kerja karyawan, kepuasan kerja berpengaruh positif signifikan terhadap semangat kerja karyawan, dan budaya organisasi berpengaruh positif signifikan terhadap semangat kerja karyawan dengan kepuasan kerja sebagai variabel mediasi.
\end{abstract}

Kata kunci: Budaya Organisasi, Semangat Kerja, Kepuasan Kerja

Abstrack: This study aims to examine the influence of organizational culture on employee morale, the influence of organizational culture on job satisfaction, the influence of job satisfaction on employee morale, and organizational culture on employee morale with job satisfaction as a mediation variable on employees Public Company of the Indonesian Tarakan Navigation Service Provisioning Agency. In this research using quantitative approach with explanatory method, sampling is done by determining sample of quota samples where from the whole population, sample is taken as desired by researcher by fulfilling criteria determined that is 50 employees of Public Company of the Indonesian Tarakan Navigation Service Provisioning Agency used as a sample. The analytical method uses an analysis tool with the help of SPSS program version 18.0. The results of this study indicate that the culture of organization has a significant positive effect on the employee morale, organizational culture have a significant positive effect 
on job satisfaction employees, job satisfaction have a significant positive effect on employee morale, and organizational culture have a significant positive effect on employee morale with job satisfaction as mediation variable.

Keywords: Organizational Culture, Employee Morale, Job Satisfaction

\section{LATAR BELAKANG}

Karyawan adalah Sumber Daya Manusia (SDM) yang merupakan aset penting dalam perusahaan. Karyawan sebagai perencana, pelaksana, bahkan pengendali yang berperan aktif dalam mewujudkan tujuan perusahaan (Andriani, 2014). Sumber daya manusia merupakan keunggulan kompetitif di pasar lokal maupun global. Kinerja organisasi dapat ditingkatkan apabila dapat mengelola sumber daya manusia dengan baik. Keberhasilan organisasi dalam mencapai tujuan ditentukan oleh kinerja organisasi yang sangat dipengaruhi oleh faktor eksternal maupun internal organisasi (Wibowo, 2011).

Semangat kerja adalah keinginan dan kesungguhan seseorang mengerjakan pekerjaannya dengan baik serta berdisiplin untuk mencapai prestasi kerja yang maksimal (Hasibuan, 2008). Tidak jauh berbeda dengan pengertian yang dinyatakan oleh Nawawi (1990), bahwa semangat kerja merupakan suasana batin karyawan yang berpengaruh pada usahanya untuk mewujudkan suatu tujuan melalui pelaksanaan pekerjaan yang menjadi tanggung jawabnya.

PERUM

Penyelenggaraan Pelayanan Navigasi Penerbangan Indonesia Cabang Tarakan yang menjadi obyek penelitian ini, budaya organisasi dalam perusahaan tersebut memiliki budaya yang kuat dan solid. Ketika membahas semangat kerja, ada sebagian karyawan yang memiliki semangat kerja yang baik, terdapat pula semangat kerja yang tidak baik. Hal ini terjadi dikarenakan adanya semangat kerja yang tidak konsisten dan selalu berubah. Kepuasan kerja karyawan pada PERUM LPPNPI Cabang Tarakan dikategorikan baik dibuktikan dari karyawan yang selalu merasa puas dengan pekerjaannya, walaupun dengan latar belakang faktor yang bervariatif.

Berdasarkan artikel oleh Barry Phegan, yang berjudul "The Benefits of A Good Organization Culture", terdapat pernyataan bahwa: "Karena budaya perusahaan mempengaruhi segala sesuatu dan setiap orang, budaya perusahaan yang berkembang dengan baik menciptakan perubahan positif di seluruh organisasi, diantaranya semangat kerja". Adanya teori yang tidak sesuai dengan fenomena yang terjadi, perlu adanya penelitian yang mampu menjawab permasalahan yang ada. Sehingga penelitian ini, akan ditambahkan variabel mediasi yang mempunyai pengertian sebagai variabel yang mampu menguatkan ataupun melemahkan pengaruh antara dua variabel atau lebih yang ada. Variabel mediasi yang dipakai dalam penelitian ini adalah variabel kepuasan kerja. 
Maka diharapkan variabel kepuasan kerja, mampu menjadi jawaban untuk dapat membuat teori sesuai dengan fenomena.

\section{RUMUSAN MASALAH}

Berdasarkan uraian di atas maka masalah yang diteliti dapat dirumuskan sebagai berikut:

1. Apakah budaya organisasi berpengaruh terhadap semangat kerja ?

2. Apakah budaya organisasi berpengaruh terhadap kepuasan kerja?

3. Apakah kepuasan kerja berpengaruh terhadap semangat kerja?

4. Apakah budaya organisasi berpengaruh terhadap semangat kerja dengan kepuasan kerja sebagai variabel mediasi ?

\section{TUJUAN PENELITIAN}

1. Untuk mengetahui adanya pegaruh budaya organisasi terhadap semangat kerja.

2. Untuk mengetahui adanya pengaruh budaya organisasi terhadap kepuasan kerja.

3. Untuk mengetahui adanya pengaruh kepuasan kerja terhadap semangat kerja.

4. Untuk mengetahui adanya pengaruh budaya organisasi terhadap semangat kerja dengan kepuasan kerja sebagai variabel mediasi.

\section{TINJAUAN PUSTAKA}

\section{Teori Manajemen Sumber Daya $\underline{\text { Manusia }}$}

Manajemen sumber daya
manusia adalah
pengorganisasian,
pengawasan, dari $\begin{array}{r}\text { pengarahan, } \\ \text { pengadaan, } \\ \text { pengembangan, }\end{array}$
kompensasi, pengintegrasian, dan pemeliharaan tenaga kerja dengan maksud untuk membantu mencapai tujuan dari perusahaan, individu, dan masyarakat.

Menurut (Ranupandjojo dan Husnan, 2002) Manajemen yang berkaitan dengan pengelolaan kegiatan pemberdayaan sumber daya manusia disebut manajemen sumber daya manusia. Pada umumnya, kegiatankegiatan di bidang sumber daya manusia dapat dilihat dari dua sudut pandang, yaitu dari sisi pekerjaan dan dari sisi pekerja. Dari sisi pekerjaan, kegiatan-kegiatan itu terdiri atas analisis pekerjaan dan evaluasi pekerjaan. Sedangkan dari sisi pekerja, kegiatan-kegiatan itu terdiri atas pengadaan tenaga kerja, penilaian prestasi kerja, pelatihan dan pengembangan, promosi, kompensasi, dan pemutusan hubungan kerja. Dengan demikian, manajemen sumber daya manusia dapat didefinisikan sebagai suatu proses yang terdiri atas perencanaan, pengorganisasian, pemimpinan, dan pengendalian kegiatan-kegiatan yang berkaitan dengan analisis pekerjaan, pengadaan, pengembangan, kompensasi, promosi, dan pemutusan hubungan kerja guna mencapai tujuan yang telah ditetapkan (Panggabean, 2004) . 
$\underline{\text { Teori Budaya Organisasi }}$

Budaya adalah suatu pola asumsi dasar yang ditemukan dan dikembangkan oleh suatu kelompok tertentu karena mempelajari dan menguasai masalah adaptasi eksternal dan integrasi internal, yang telah bekerja dengan cukup baik untuk dipertimbangkan secara layak dan karena itu diajarkan pada anggota baru sebagai cara yang dipersepsikan, berpikir dan dirasakan dengan benar dalam hubungan dengan masalah tersebut (Schein, 1997). Budaya organisasi merupakan hasil dari suatu proses mencairkan dan meleburkan gaya budaya dan atau perilaku tiap individu yang dibawa sebelumnya ke dalam sebuah norma-norma dan filosofi yang baru, yang memiliki energi serta kebanggan kelompok dalam menghadapi sesuatu dan tujuan tertentu. (Edison, Anwar, dan Komariyah, 1997).

Gibson, Ivancevich, dan Donelly (2000), menyatakan bahwa budaya organisasi adalah sebuah pola asumsi dasar yang cukup bekerja baik untuk dipertimbangkan dengan layak, dan karena itu diajarkan kepada anggota baru sebagai cara yang benar untuk mempersepsikan, berpikir, dan merasa dalam hubungannya dengan masalah tersebut. Sehingga, pengertian budaya organisasi dikatakan sebagai apa yang dirasakan pekerja dan bagaimana persepsi ini menciptakan pola keyakinan, nilai-nilai, dan harapan.

\section{Tipe Budaya Organisasi}

Sesuai dengan pemahaman sebelumnya, budaya organisasi merupakan filosofi dasar organisasi yang memuat keyakinan, norma-norma dan nilai-nilai bersama yang menjadi karakteristik inti tentang bagaimana cara melakukan sesuatu dalam organisasi. Luasnya pengertian budaya organisasi tersebut membuka peluang timbulnya berbagai pandangan pula tentang adanya tipe-tipe budaya organisasi. Pendapat mereka beragam dengan justifikasi dan sudut pandang masing-masing. (Wibowo, 2011)

$$
\text { Robbins }
$$

(2001), mengelompokkan tipe budaya menjadi networked culture, mercenary culture, fragmented culture, dan communal culture. Penetapan tipe budaya tersebut dilakukan dengan menarik hubungan antara tingkat sosiabilitas dan solidaritas. Dimensi sosiabilitas ditandai oleh tingkat persahabatan terutama ditemukan di antara anggota organisasi. Adapun dimensi solidaritas ditandai oleh tingkatan di mana orang dalam organisasi berbagi pengertian bersama tentang tugas dan tujuan untuk apa mereka bekerja.

\section{Networked culture}

Organisasi memandang anggota sebagai suatu keluarga dan teman (high on sociability, low on solidarity). Budaya ini ditandai oleh tingkat sosiabilitas atau kesenangan bergaul tinggi dan tingkat solidaritas atau kesetiakawanan rendah. Network culture sangat bersahabat dan bersuka ria dalam gaya. Orang cenderung. membiarkan pintunya terbuka, berbicara tentang bisnis secara bebas, kebiasaan informal, dan menggunakan banyak waktu untuk sosialisasi, dan tanpa mendapatkan masalah karenanya. Orang biasanya saling mengetahui satu sama lain dengan cepat dan merasa bahwa mereka adalah bagian dari kelompok. 


\section{Mercenary culture}

Organisasi memfokus pada tujuan (low on sociability, high on solidarity). Budaya organisasi ini ditandai oleh tingkat sosiabilitas rendah dan tingkat solidaritas tinggi. Mercenary culture melibatkan orang yang sangat fokus dalam menarik bersama untuk membuat pekerjaan dilakukan. Komunikasi cenderung cepat, langsung, dan dikendalikan dengan cara yang tidak ada yang tidak mungkin. Kebiasaan seperti menonjolkan bisnis dan omong kosong tidak ada toleransi, karena menghabiskan waktu saja. Kemenangan adalah segalanya dan orang didorong melakukan berapa lama pun waktu diperlukan untuk membuatnya terwujud.

\section{Fragmented culture}

Organisasi yang dibuat dari para individualis (low on sociability, low on solidarity). Budaya ini ditandai oleh solidaritas dan sosiabilitas rendah. Orang yang bekerja dalam fragmented culture sedikit melakukan kontak dan dalam banyak hal mereka bahkan tidak saling mengenal. Meskipun pekerja akan berbicara dengan orang lain apabila dirasakan perlu dan berguna untuk melakukannya, orang biasanya meninggalkannya sendiri. Tidak heran bahwa anggota fragmented culture tidak menampakkan identifikasi dengan organisasi mana ia bekerja. Sebaliknya, mereka cenderung mengidentifikasi dengan profesi di mana mereka menjadi bagiannya.

\section{Communal culture}

Organisasi menilai baik persahabatan dan kinerja (high on sociability, high on solidarity). Budaya ini ditandai oleh sosiabilitas dan solidaritas tinggi. Anggota communal culture sangat bersahabat satu sama lain dan bergaul dengan baik, baik secara pribadi maupun profesional. Communal culture sangat luas terdapat pada perusahaan teknologi tinggi, terutama yang dimulai dengan internet. Karena individu dalam organisasi seperti ini cenderung berbagi dalam banyak hal, sering sulit menentukan siapa ditunjuk pada kantor tertentu. Komunikasi mengalir dengan sangat mudah, diantara orang orang pada semua tingkatan organisasi dan dalam semua bentuk. Setiap orang sangat bersahabat sehingga perbedaan antara pekerjaan dan bukan pekerjaan dalam praktik menjadi kabur. Pekerja sangat kuat mengidentifikasi dengan communal organization. Mereka mengenakan logo perusahaan, mereka hidup dalam kepercayaan perusahaan dan mereka sangat membela ketika berbicara dengan orang luar.

\section{$\underline{\text { Karakteristik Budaya Organisasi }}$}

Budaya organisasi dalam suatu organisasi yang satu dapat berbeda dengan yang ada dalam organisasi lain. Namun, budaya organisasi menunjukkan ciri-ciri, sifat, atau karakteristik tertentu yang menunjukkan kesamaannya. Terminologi yang dipergunakan para ahli untuk menunjukkan karakteristik budaya organisasi bervariasi. Hal tersebut menunjukkan beragamnya ciri, sifat, dan elemen yang terdapat dalam budaya organisasi. (Wibowo, 2011) Greenberg dan Baron (1997), mengemukakan bahwa terdapat tujuh elemen yang menunjukkan karakteristik budaya organisasi, antara lain :

1. Innovation (inovasi), suatu tingkatan di mana orang 
diharapkan kreatif dan membangkitkan gagasan baru.

2. Stability (stabilitas), bersifat menghargai lingkungan yang stabil, dapat diperkirakan, dan berorientasi pada peraturan.

3. Orientation toward people (orientasi pada orang), merupakan orientasi untuk menjadi jujur, mendukung, dan menunjukkan penghargaan pada hak individual.

4. Result-orientation people (orientasi pada hasil), meletakkan kekuatannya pada kepeduliannya untuk mencapai hasil yang diharapkan.

5. Easygoingness (bersikap tenang), suatu keadaan di mana tercipta iklim kerja bersifat santai.

6. Attention to detail (perhatian pada hal detail), dimaksudkan dengan berkepentingan untuk menjadi analitis dan seksama.

7. Collaborative orientation (orientasi pada kolaborasi), merupakan orientasi yang menekankan pada bekerja dalam tim sebagai lawan dari bekerja secara individual.

Robbins (2001) juga

mengemukakan adanya tujuh

karakteristik budaya organisasi, antara

lain:

1. Innovation and risk taking (inovasi dan pengambilan resiko), suatu tingkatan di mana pekerja didorong untuk menjadi inovatif dan megambil resiko.

2. Attention to detail (perhatian pada hal detail), di mana pekerja diharapkan menunjukkan ketepatan, analisis, dan perhatian pada hal detail.

3. Outcome orientation (orientasi pada manfaat), di mana manajemen terfokus pada hasil atau manfaat daripada sekadar teknik dan proses yang dipergunakan untuk mendapatkan manfaat tersebut.

4. People orientation (orientasi pada orang), di mana keputusan manajemen mempertimbangkan pengaruh manfaatnya pada orang dalam organisasi.

5. Team orientation (orientasi pada tim), di mana aktivitas kerja diorganisasi berdasar tim daripada individual.

6. Aggressiveness (agresivitas), di mana orang cenderung lebih agresif dan kompetitif daripada easygoing .

7. Stability (stabilitas), di mana aktivitas organisasional menekankan pada menjaga status quo sebagai lawan dari perkembangan.

\section{$\underline{\text { Fungsi Budaya Organisasi }}$}

Fungsi budaya organisasi menunjukkan peranan atau kegunaan dari budaya organisasi. Fungsi budaya organisasi menurut Kreitner dan Kinicki (2001) adalah :

1. Memberi anggota identitas organisasional, menjadikan perusahaan diakui sebagai perusahaan yang inovatif dengan mengembangkan produk baru. Identitas organisasi menunjukkan ciri khas yang membedakan dengan organisasi lain yang mempunyai sifat khas yang berbeda.

2. Memfasilitasi komitmen kolektif, perusahaan mampu membuat pekerjanya bangga menjadi bagian daripadanya. Anggota organisasi mempunyai komitmen bersama tentang norma-norma dalam organisasi yang harus diikuti dan tujuan bersama yang harus dicapai.

3. Meningkatkan stabilitas sistem sosial sehingga mencerminkan 
bahwa lingkungan kerja dirasakan positif dan diperkuat, konflik dan perubahan dapat dikelola secara efektif. Dengan kesepakatan bersama tentang budaya organisasi yang harus dijalani mampu membuat lingkungan dan interaksi sosial berjalan dengan stabil dan tanpa gejolak.

4. Membentuk perilaku dengan membantu anggota menyadari atas lingkungannya. Budaya organisasi dapat menjadi alat untuk membuat orang berpikiran sehat dan masuk akal.

\section{$\underline{\text { Teori Semangat Kerja }}$}

Semangat kerja adalah keinginan dan kesungguhan seseorang mengerjakan pekerjaannya dengan baik serta berdisiplin untuk mencapai prestasi kerja yang maksimal (Hasibuan, 2008). Menurut Nawawi (1990), semangat kerja merupakan suasana batin seorang karyawan yang berpengaruh pada usahanya untuk mewujudkan suatu tujuan melalui pelaksanaan pekerjaan yang menjadi tanggung jawabnya. Berdasarkan uraian diatas dapat disimpulkan, yang dimaksud dengan semangat kerja adalah suasana batin yang berpengaruh terhadap usaha untuk melakukan pekerjaan secara giat. Dalam bekerja didasarkan atas rasa percaya diri, motivasi diri yang kuat, serta disertai rasa tetap gembira dalam melaksanakan dan menyelesaikan pekerjaan dengan baik(Asnawi, 1999).

\section{Faktor-Faktor Yang Mempengaruhi Semangat Kerja}

Terdapat beberapa faktor yang turut mempengaruhi tinggi rendahnya semangat kerja dalam organisasi menurut Jauhari (2015), antara lain:

a. Hubungan yang harmonis antara atasan dan bawahan terutama antara pimpinan yang sehari-hari langsung berhubungan dan berhadapan dengan karyawan bawahannya.

b. Kepuasan kerja terhadap tugas dan pekerjaan yang diembannya.

c. Terdapat suasana atau iklim kerja yang bersahabat dengan anggotaanggota lainnya.

d. Rasa kemanfaatan bagi tercapainya tujuan organisasi yang merupakan tujuan bersama dan harus diwujudkan secara bersama pula.

e. Adanya kepuasan tingkat ekonomi dan adanya kepuasan material lainnya yang memadai sebagai imbalan yang dirasakan adil terhadap jerih payah yang telah diberikan kepada organisasi.

f. Adanya ketenangan jiwa, jaminan kepastian, serta perlindungan terhadap segala sesuatu yang dapat membahayakan diri dan karier dalam pekerjaan.

Menurut Panggabean (2004), beberapa faktor yang dapat mempengaruhi semangat kerja meliputi :

1) Kondisi pekerjaan

Seseorang yang mengerjakan pekerjaan yang disenangi, maka dirinya akan mempunyai semangat kerja yang lebih tinggi daripada mengerjakan pekerjaan yang tidak disenanginya.

2) Rekan kerja

Hubungan kerja antar anggota organisasi perlu dibina, agar para anggota akan saling membantu dalam menyelesaikan tugas dan tujuan perusahaan. Hubungan kerja tidak 
hanya bersifat formal, tetapi juga tidak kalah pentingnya hubungan batin yang bersifat tidak formal.

\section{3) Pimpinan}

Kepemimpinan tidak hanya tergantung pada suatu masa dan juga tidak hanya menyangkut hubungan atasan dan bawahan saja, tetapi terjadi disaat seseorang berusaha mempengaruhi tingkah laku orang lain atau kelompok dalam situasi tertentu.

\section{4) Organisasi/Perusahaan}

Sistem dan prosedur kerja dalam organisasi yang merupakan suatu aturan yang mengatur hubungan kerja antar anggota dengan organisasinya, termasuk hak dan kewajiban para anggota yang secara tidak langsung akan berpengaruh terhadap semangat kerja para anggota organisasi.

\section{5) Lingkungan}

Lingkungan kerja yang baik akan mendorong seseorang untuk bekerja lebih baik dan bersikap positif seperti mempunyai kesetiaan yang tinggi, kegembiraan, kebanggaan dalam pekerjaannya, kerjasama dan kedisiplinan yang tinggi

\section{$\underline{\text { Teori Kepuasan Kerja }}$}

Handoko (2014) menyatakan bahwa kepuasan kerja adalah keadaan emosional karyawan yang menyenangkan atau tidak menyenangkan dalam memandang pekerjaan mereka. Kepuasan kerja mencerminkan perasaan seseorang terhadap pekerjaanya. Berdasarkan Mangkunegara (2008) kepuasan kerja adalah perasaan yang menyokong atau tidak menyokong karyawan yang berhubungan dengan pekerjaan maupun dengan kondisi karyawan. Perasaan yang berhubungan dengan pekerjaan melibatkan aspek-aspek seperti upah atau gaji yang diterima, kesempatan pengembangan karir, hubungan dengan pegawai lainnya, penempatan kerja, jenis pekerjaan, struktur organisasi perusahaan, mutu pengawasan, dan lain-lain. Sedangkan perasaan yang berhubungan dengan karyawan, yaitu umur, kondisi kesehatan, kemampuan, dan pendidikan. Badriyah (2015) menyatakan bahwa kepuasan kerja adalah sikap atau perasaan karyawan terhadap aspek-aspek yang menyenangkan atau tidak menyenangkan mengenai pekerjaan yang sesuai dengan penilaian masingmasing pekerja.

\section{Faktor-faktor yang Mempengaruhi Kepuasan Kerja}

Menurut Luthans (2006), faktor-faktor yang mempengaruhi kepuasan kerja adalah:

1. Kompensasi

Kompensasi atau upah merupakan karakteristik pekerjaan yang menjadi penyebab paling mungkin terhadap ketidakpuasan kerja. Upah yang diberikan untuk seseorang dalam posisi yang sama merupakan satu penyebab terhadap keyakinan seseorang tentang seberapa besar gaji yang harus diterima. Semakin tinggi tingkat pendidikan dan profesional seseorang semakin tinggi kemungkinan ia melakukan perbandingan sosial dengan orang-orang yang profesinya sama di luar organisasi. Selain itu, kepuasan terhadap upah akan dipengaruhi oleh kebutuhan dan nilai-nilai seseorang. Jika upah seseorang cukup untuk memenuhi kebutuhan keluarga dan dirinya, ia akan lebih puas dibandingkan jika ia menerima upah lebih rendah dari yang diperlukan 
untuk memenuhi standar hidup yang memadai.

\section{Kesempatan promosi}

Promosi terjadi pada saat seorang pekerja berpindah dari suatu pekerjaan ke posisi yang lebih tinggi dengan tanggung jawab dan jenjang organisasionalnya. Pada saat dipromosikan, pekerja umumnya menghadapi peningkatan tuntutan dan keahlian, kamampuan dan tanggung jawab. Sebagian besar pekerja merasa positif karena dipromosikan. Promosi memungkinkan perusahaan untuk mendayagunakan kemampuan dan keahlian pekerja setinggi mungkin.

3. Pengawasan (supervisi)

Supervisi mempunyai peran yang penting dalam manajemen. Supervisi berhubungan dengan anggota organisasi secara langsung dan mempengaruhi anggota dalam melakukan pekerjaannya. Umumnya anggota lebih suka mempunyai supervisi yang adil, terbuka dan mau bekerjasama dengan bawahan.

\section{Rekan kerja}

Bagi kebanyakan individu, kerja juga mengisi kebutuhan akan interaksi sosial. Oleh karena itu, tidaklah mengejutkan apabila mempunyai rekan kerja yang pandai secara teknis dan mendukung secara sosial dapat meningkatkan kepuasan kerja.

\section{Pekerjaan itu sendiri}

Seseorang cenderung lebih menyukai pekerjaan-pekerjaan yang memberi kesempatan untuk menggunakan kemampuan dan keterampilannya, kebebasan, dan umpan balik mengenai betapa baik mereka bekerja. Karakteristik ini membuat kerja lebih menantang. Pekerjaan yang kurang menantang menciptakan kebosanan, tetapi yang terlalu banyak menantang juga dapat menciptakan frustasi dan perasaan gagal.

Harold E. Burt dalam Anoraga (2006) mengemukakan pendapatnya tentang faktor-faktor yang ikut menentukan kepuasan kerja sebagai berikut :

1) Faktor hubungan antar karyawan, antara lain :

a. Hubungan langsung antara manajer dengan karyawan

b. Faktor psikis dan kondisi kerja

c. Hubungan sosial diantara karyawan

d. Sugesti dari teman sekerja

e. Emosi dan situasi kerja

2) Faktor-faktor individual, yaitu yang berhubungan dengan :

a. Sikap

b. Umur

c. Jenis kelamin

3) Faktor-faktor luar, yaitu hal-hal yang berhubungan dengan :

a. Keadaan keluarga karyawan

b. Rekreasi

c. Pendidikan

$\underline{\text { Penelitian Terdahulu }}$

Jauhari (2015), dalam penelitian yang berjudul Pengaruh Budaya Organisasi Terhadap Semangat Kerja Pegawai Bagian Umum Sekretariat Daerah Kabupaten Boyolali. Hasil penelitian menunjukkan bahwa variabel budaya organisasi berpengaruh terhadap semangat kerja pegawai pada Bagian Umum Sekretariat Daerah Kabupaten Boyolali. Failasufah (2011), dalam penelitian yang berjudul Pengaruh Kepuasan Kerja dan Budaya Organisasi Terhadap Semangat Kerja Guru di SMA Negeri 1 Pecangaan Jepara. Hasil penelitian menunjukkan bahwa ada pengaruh budaya organisasi 
sekolah terhadap semangat kerja guru di SMA Negeri 1 Pecangaan Jepara.

Herawan, dkk.(2015), dalam penelitian yang berjudul Pengaruh Budaya Organisasi Terhadap Kepuasan Kerja Karyawan Studi Pada PT. Bank Rakyat Indonesia (Persero) Kantor Cabang Kota Malang Kawi. Hasil penelitian menunjukkan bahwa Kepuasan Kerja dipengaruhi oleh Budaya Organisasi. Andriani (2014), dalam penelitian yang berjudul Pengaruh Budaya Organisasi dan Kompetensi Terhadap Kepuasan Kerja Karyawan Pada Bank Tabungan Negara di Bandung. Hasil penelitian menunjukkan bahwa budaya organisasi berpengaruh positif terhadap kepuasan kerja karyawan.

Fahmi (2014), dalam penelitian yang berjudul Pengaruh Kepuasan Kerja dan Besarnya Gaji Terhadap Semangat Kerja Karyawan Non Medis RSUD Sunan Kalijaga Kabupaten Demak Tahun 2012/2013. Hasil penelitian menunjukkan bahwa variabel kepuasan kerja berpengaruh terhadap semangat kerja karyawan nonmedis RSUD Sunan Kalijaga Kabupaten Demak Tahun 2012/2013. Failasufah (2011), dalam penelitian yang berjudul Pengaruh Kepuasan Kerja dan Budaya Organisasi Terhadap Semangat Kerja Guru di SMA Negeri 1 Pecangaan Jepara. Hasil penelitian menunjukkan bahwa ada pengaruh kepuasan kerja terhadap semangat kerja guru di SMA Negeri 1 Pecangaan Jepara.

\section{Definisi Konseptual}

\section{Budaya Organisasi}

Budaya organisasi merupakan pengendali dan arah dalam membentuk sikap dan perilaku para anggota di dalam suatu organisasi. (Josiah, 2011)

\section{Semangat Kerja}

Semangat kerja adalah suasana batin yang berpengaruh terhadap usaha untuk melakukan pekerjaan secara giat. Dalam bekerja didasarkan atas rasa percaya diri, motivasi diri yang kuat, serta disertai rasa tetap gembira dalam melaksanakan pekerjaan, untuk menyelesaikan pekerjaan dengan baik. (Asnawi, 1999).

\section{Kepuasan Kerja}

Kepuasan kerja merupakan keadaan emosional seseorang atas pekerjaannya yang bisa dipengaruhi oleh supervisi, kondisi kerja, dan lingkungan kerja (Failasufah, 2011).

\section{$\underline{\text { Hipotesis }}$}

H1 : Budaya organisasi berpengaruh positif terhadap Semangat kerja

$\mathrm{H} 2$ : Budaya organisasi berpengaruh positif terhadap Kepuasan kerja H3 : Kepuasan kerja berpengaruh positif terhadap Semangat kerja H4 : Budaya organisasi berpengaruh positif terhadap Semangat kerja dengan Kepuasan kerja sebagai variabel mediasi 


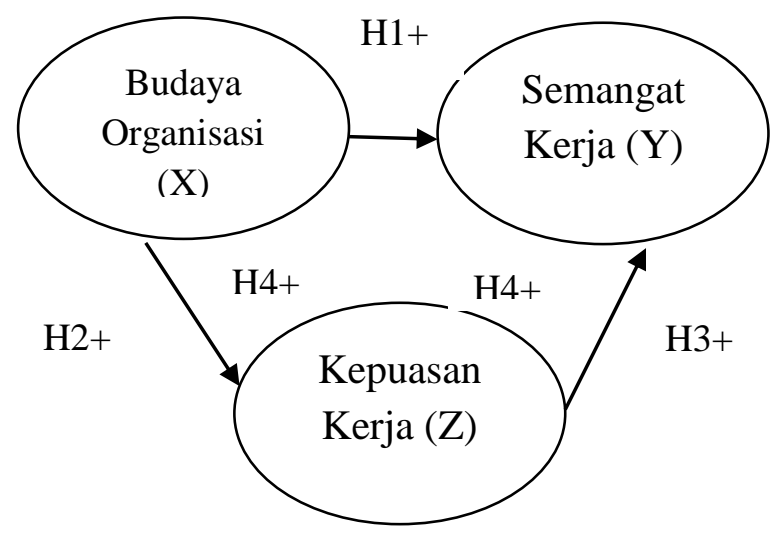

METODOLOGI PENELITIAN

\section{$\underline{\text { Desain Penelitian }}$}

Jenis penelitian yang digunakan dalam penelitian ini adalah penelitian explanatory. Penelitian explanatory adalah penelitian yang bersifat penjelasan di mana penelitian ini menyoroti hubungan antara variabelvariabel independen terhadap variabel dependen dan menguji hipotesis yang telah dirumuskan sebelumnya (Singarimbun \& Effendi, 1990).

Menurut Sugiyono (2012), jenis penelitian ini dilihat dari sifat-sifat masalahnya merupakan penelitian kausal komparatif yang menunjukkan hubungan sebab akibat antara satu variabel dengan variabel lainnya.

\section{$\underline{\text { Populasi dan Sampel }}$}

Menurut Sugiyono (2007) menjelaskan bahwa: "Populasi adalah wilayah generalisasi yang terdiri atas objek atau subjek yang mempunyai kualitas dan karakteristik tertentu yang di tetapkan oleh peneliti untuk mempelajari kemudian ditarik kesimpulan". Populasi dalam penelitian ini adalah seluruh karyawan
PERUM LPPNPI Cabang Tarakan yang berjumlah sebanyak 67 orang.

Menurut Sugiyono (2007) menjelaskan bahwa: "Sampel adalah bagian dari jumlah dan karakteristik yang dimiliki oleh populasi tersebut". Peneliti menggunakan teknik sampling quota untuk memilih responden. Sampling Quota menurut Kuncoro (2012) adalah metode yang digunakan untuk memastikan bahwa berbagai subgrup dalam populasi telah terwakili dengan berbagai karakteristik sampel sampai batas tertentu seperti yang dikehendaki oleh peneliti. Pada PERUM LPPNPI Cabang Tarakan, perusahaan ini memiliki karyawan yang terbagi dalam empat subgrup yang umum, antara lain: manajemen operasional, manajemen teknik, manajemen safety (keselamatan dan keamanan), dan manajemen administrasi dan keuangan. Dalam penelitian ini, peneliti mengambil sampel dari beberapa karyawan yang masing-masing bekerja dalam keempat subgrup tersebut, yang telah mewakili karyawan perusahaan secara keseluruhan dan memenuhi syarat sampling quota. Jumlah sampel yang diambil sebanyak 50 responden dari sebagian karyawan PERUM LPPNPI Cabang Tarakan.

\section{Data Penelitian}

Jenis dan Sumber Data

Jenis Data yang digunakan adalah data primer. Data primer merupakan data yang diperoleh langsung dari sumbernya. Pengumpulan data primer dilakukan dalam upaya untuk menyediakan data yang siap untuk dianalisis (Karsini, dkk. 2016). 
Sumber data yang diperoleh penulis dalam penelitian, merupakan data yang diperoleh langsung dari sebagian karyawan PERUM LPPNPI Cabang Tarakan.

\section{$\underline{\text { Teknik Pengumpulan Data }}$}

Pengumpulan data dilakukan dengan cara penelitian lapangan yang merupakan metode penelitian mengenai permasalahan yang ada secara langsung ke objek penelitian untuk mendapatkan laporan tahunan organisasi/lembaga guna memperoleh data primer berupa laporan dan data lainnya. Penelitian lapangan menurut (Damayanti, 2015) yaitu seperti menggunakan instrumen kuesioner.

Kuesioner adalah sejumlah pertanyaan tertulis yang digunakan untuk memperoleh informasi dari responden dalam arti laporan tentang pribadinya atau hal-hal yang ia ketahui (Arikunto, 2006). Jenis instrumen yang digunakan dalam penelitian ini berupa skala Likert yaitu skala yang berisi lima tingkat preferensi jawaban dengan pilihan sebagai berikut (Ghozali, 2007):

a. Skor 5 jika jawaban responden sangat setuju

b. Skor 4 jika jawaban responden setuju

c. Skor 3 jika jawaban responden ragu-ragu

d. Skor 2 jika jawaban responden tidak setuju

e. Skor 1 jika jawaban responden sangat tidak setuju

Variabel Penelitian dan Definisi

Variabel Penelitian

$\underline{\text { Variabel Penelitian }}$
Variabel penelitian adalah objek penelitian atau apa yang menjadi titik perhatian suatu penelitian (Arikunto, 2006). Variabel dalam penelitian ini dibedakan menjadi tiga yaitu variabel bebas (independen), variabel terikat (dependen), dan variabel mediasi (mediator) yang diuraikan sebagai berikut:

1. Variabel Bebas (Independent Variable)

Variabel bebas merupakan variabel yang mempengaruhi atau yang menjadi sebab perubahannya atau timbulnya variabel terikat (Sugiyono, 2012). Variabel independen disimbolkan dengan "X". Variabel bebas yang digunakan pada penelitian ini adalah Budaya Organisasi yang disimbolkan dengan "X".

2. Variabel Terikat (Dependent Variable)

Variabel terikat merupakan variabel yang dipengaruhi atau yang menjadi akibat karena adanya variabel bebas (Sugiyono, 2012). Variabel dependen disimbolkan dengan "Y". Variabel terikat yang digunakan pada penelitian ini adalah Semangat Kerja yang disimbolkan dengan "Y".

\section{Variabel Mediasi (Mediating} Variable)

Variabel mediasi adalah variabel yang bersifat menjadi perantara (mediating) dari hubungan variabel penjelas ke variabel tergantung. Sifatnya adalah sebagai penghubung ("jembatan") antara variabel penjelas dengan variabel tergantung (bisa bersifat partial atau complete mediation) (Solimun, 2008). Variabel mediasi disimbolkan dengan "Z". Variabel mediasi yang digunakan pada penelitian ini adalah Kepuasan Kerja yang disimbolkan dengan " $Z$ ". 
Definisi Operasional

Budaya Organisasi

Budaya organisasi sebagai kerangka kerja kognitif yang terdiri dari sikap, nilai-nilai, norma perilaku dan harapan yang diterima bersama oleh anggota organisasi. Akar setiap budaya organisasi adalah serangkaian karateristik inti yang dihargai secara kolektif oleh anggota organisasi. (Greenberg dan Baron, 1997).

Robbins (2001) mengemukakan adanya tujuh karakteristik budaya organisasi, antara lain:

1. Innovation and risk taking (inovasi dan pengambilan resiko), karyawan PERUM LPPNPI Cabang Tarakan termotivasi untuk selalu inovatif dan berani megambil resiko dalam bekerja.

2. Attention to detail (perhatian pada hal detail), karyawan PERUM LPPNPI Cabang Tarakan dalam bekerja selalu tepat, melakukan analisis, dan mempunyai perhatian yang penuh terhadap pekerjaannya.

3. Outcome orientation (orientasi pada manfaat), manajemen PERUM LPPNPI Cabang Tarakan terfokus pada hasil dan manfaat.

4. People orientation (orientasi pada orang), keputusan manajemen PERUM LPPNPI Cabang Tarakan selalu mempertimbangkan pengaruh manfaatnya pada karyawan dalam organisasi.

5. Team orientation (orientasi pada tim), aktivitas kerja PERUM LPPNPI Cabang Tarakan berdasar tim daripada individual.

6. Stability (stabilitas), aktivitas organisasional PERUM LPPNPI Cabang Tarakan cenderung menjaga stabilitas kinerja karyawan.

\section{$\underline{\text { Semangat Kerja }}$}

Semangat kerja adalah keinginan dan kesungguhan seseorang mengerjakan pekerjaannya dengan baik serta berdisiplin untuk mencapai prestasi kerja yang maksimal (Hasibuan, 2008) Menurut Panggabean (2004), beberapa faktor yang dapat mempengaruhi semangat kerja meliputi :

1. Kondisi pekerjaan

Karyawan PERUM LPPNPI Cabang Tarakan mengerjakan pekerjaannya dengan semangat kerja yang tinggi.

2. Rekan kerja

Hubungan kerja antar anggota perusahaan PERUM LPPNPI Cabang Tarakan terbina dengan baik.

3. Pimpinan

Pimpinan perusahaan PERUM LPPNPI Cabang Tarakan mampu berinteraksi dan mempengaruhi secara baik tingkah laku anggota organisasi.

4. Organisasi/Perusahaan

Sistem dan prosedur kerja dalam PERUM LPPNPI Cabang Tarakan sudah sangat jelas.

\section{Lingkungan}

Lingkungan kerja PERUM LPPNPI Cabang Tarakan mendorong karyawan untuk bekerja lebih baik dan bersikap positif.

\section{$\underline{\text { Kepuasan Kerja }}$}

Handoko (2014) menyatakan bahwa kepuasan kerja adalah keadaan emosional karyawan yang menyenangkan atau tidak menyenangkan dalam memandang pekerjaan mereka. Kepuasan kerja mencerminkan perasaan seseorang terhadap pekerjaanya. Menurut Luthans (2006), faktor-faktor yang mempengaruhi kepuasan kerja adalah: 
1. Kesempatan promosi

Tidak ada kesempatan promosi yang diberikan perusahaan PERUM LPPNPI Cabang Tarakan kepada karyawan.

2. Pengawasan (supervisi)

Karyawan PERUM LPPNPI Cabang

Tarakan mempunyai supervisi yang adil, terbuka, dan mau bekerjasama dengan bawahan.

3. Rekan kerja

Rekan kerja yang pandai secara teknis dan mendukung secara sosial dapat meningkatkan kepuasan kerja karyawan PERUM LPPNPI Cabang Tarakan.

4. Pekerjaan itu sendiri

Karyawan PERUM LPPNPI Cabang Tarakan cenderung lebih menyukai pekerjaan-pekerjaan yang memberi kesempatan untuk menggunakan kemampuan dan keterampilan, kebebasan, dan umpan balik mengenai betapa baik mereka bekerja.

\section{$\underline{\text { Metode Analisis Data }}$}

Analisis data merupakan kegiatan setelah data dari seluruh responden atau sumber data terkumpul. Kegiatan dalam analisis data adalah: mengelompokkan data berdasarkan variabel dari seluruh responden, menyajikan data tiap variabel yang diteliti, melakukan perhitungan untuk menguji hipotesis yang telah diajukan (Sugiyono, 2012). Adapun metode analisis data yang digunakan dalam penelitian ini terdiri dari Uji Validitas dan Uji Reliabilitas.Berikut diuraikan metode analisis data dalam penelitian ini.

\section{$\underline{\text { Uji Validitas }}$}

Menurut Ghozali (2007), uji validitas digunakan untuk mengukur sah atau valid tidaknya suatu kuesioner. Suatu kuesioner dikatakan valid jika pertanyaan pada kuesioner mampu untuk mengungkapkan sesuatu yang diukur oleh kuesioner tersebut.Item pernyataan valid apabila rhitung lebih besar dari rtabel (rhitung $>$ rtabel) dan jika rhitung lebih kecil dari rtabel (rhitung < rtabel), maka item pernyataan tersebut tidak valid.

\section{$\underline{\text { Uji Reliabilitas }}$}

Reliabilitas menunjuk pada satu pengertian bahwa instrumen cukup dapat dipercaya dan digunakan sebagai alat pengumpul data karena instrumen tersebut sudah baik. (Arikunto, 2006). Pengujian reliabilitas dengan bantuan SPSS menggunakan metode Cronbach's Alpha, maka rhitung diwakili oleh nilai alpa. Jika nilai Cronbach's Alpha > 0,60 maka kuesioner yang diuji coba terbukti reliabel.(Arikunto, 2006).

\section{$\underline{\text { Regresi Linear Bertingkat }}$}

Alat analisis yang digunakan adalah analisis regresi linear bertingkat. Analisis regresi linear bertingkat merupakan gabungan antara regresi linear sederhana dan regresi linear berganda (Sumarni, 2016). Langkah-langkah yang harus dilakukan untuk menguji variabel mediasi dalam penelitian ini, berdasarkan pada model digambarkan sebagai berikut :

$$
\begin{aligned}
& \mathrm{Y}=\mathrm{a}+\mathrm{b} 1 \mathrm{X} 1 \ldots(1) \\
& \mathrm{Y}=\mathrm{a}+\mathrm{b} 1 \mathrm{X} 1+\mathrm{b} 2 \mathrm{X} 2 \ldots(2) \\
& \mathrm{Y}=\mathrm{a}+\mathrm{b} 1 \mathrm{X} 1+\mathrm{b} 2 \mathrm{X} 2+\mathrm{Z} \ldots(3) \\
& \text { Keterangan : } \\
& \mathrm{Y} \quad=\text { Semangat Kerja } \\
& \mathrm{A} \quad=\text { Konstanta } \\
& \beta 1 \mathrm{X} 1=\text { Koefisien Regresi Budaya } \\
& \text { Organisasi }
\end{aligned}
$$


$\beta 2 X 2=$ Koefisien Regresi Kepuasan Kerja

$\mathrm{Z}=$ Pengaruh Efek Mediasi

1. Kriteria hipotesis diterima, jika nilai thitung $>$ ttabel $\alpha=5 \%$

2. Kriteria hipotesis ditolak, jika nilai thitung $<$ ttabel $\alpha=5 \%$

\section{HASIL PENELITIAN}

Hipotesis 1: Budaya Organisasi

berpengaruh positif signifikan

terhadap Semangat Kerja

Hasil uji hipotesis memiliki nilai $\beta 0.487$ dan thitung sebesar 4.042 signifikan pada $\alpha=5 \%$ (on tailed) nilai ttabel 1.679. Nilai thitung > ttabel. Hal tersebut menunjukkan Budaya Organisasi berpengaruh positif signifikan terhadap Semangat Kerja. Dengan demikian, dapat disimpulkan bahwa hipotesis 1 diterima.

Hipotesis 2: Budaya Organisasi berpengaruh positif signifikan terhadap Kepuasan Kerja

Hasil uji hipotesis menunjukkan bahwa hubungan tersebut memiliki nilai $\beta 0.339$ dan thitung sebesar 2.416 signifikan pada $\alpha$ $=5 \%$ (on tailed $)$ nilai tabel 1.679. Nilai thitung > ttabel. Hal tersebut menunjukkan Budaya Organisasi berpengaruh positif signifikan terhadap Kepuasan Kerja. Dengan demikian, dapat disimpulkan bahwa hipotesis 2 diterima.
Hipotesis 3: Kepuasan Kerja

berpengaruh positif signifikan

terhadap Semangat Kerja

Hasil uji hipotesis menunjukkan bahwa hubungan tersebut memiliki nilai $\beta 0.310$ dan thitung sebesar 2.576 signifikan pada $\alpha$ $=5 \%$ (on tailed) nilai tabel 1.679. Nilai thitung $>\mathrm{t}$ tabel. Hal tersebut menunjukkan Kepuasan Kerja berpengaruh positif signifikan terhadap Semangat Kerja. Dengan demikian, dapat disimpulkan bahwa hipotesis 3 diterima.

Hipotesis 4: Budaya Organisasi berpengaruh positif signifikan terhadap Semangat Kerja dengan Kepuasan Kerja Sebagai Variabel.

$\underline{\text { Mediasi }}$

Hasil uji hipotesis menunjukkan bahwa hubungan tersebut memiliki nilai $\beta 0.784$ dan thitung sebesar 4.042 signifikan pada $\alpha$ $=5 \%$ (on tailed) nilai tabel 1.679. Nilai thitung > ttabel. Hal tersebut menunjukkan Budaya Organisasi berpengaruh positif signifikan terhadap Semangat Kerja dengan Kepuasan Kerja sebagai variabel mediasi. Dengan demikian, dapat disimpulkan bahwa hipotesis 4 diterima.

$\underline{\text { Pembahasan }}$

Budaya Organisasi Berpengaruh Positif Signifikan Terhadap Semangat Kerja

Variabel budaya organisasi berpengaruh positif dan signifikan terhadap semangat kerja. Hal tersebut membuktikan bahwa jika budaya organisasi baik, maka semangat kerja 
karyawan akan tinggi. Karyawan PERUM LPPNPI Cabang Tarakan dalam bekerja selalu tepat, melakukan analisis, dan mempunyai perhatian yang penuh terhadap pekerjaannya, serta termotivasi untuk selalu inovatif dan berani mengambil resiko dalam bekerja, juga aktivitas organisasional PERUM LPPNPI Cabang Tarakan cenderung menjaga stabilitas kinerja karyawan. Dari ketiga pernyataan tersebut, dapat disimpulkan bahwa budaya organisasi PERUM LPPNPI Cabang Tarakan dapat dikatakan baik. Kemudian dalam hubungannya dengan semangat kerja, Lingkungan kerja PERUM LPPNPI Cabang Tarakan mendorong karyawan untuk bekerja lebih baik dan bersikap positif, serta Karyawan PERUM LPPNPI Cabang Tarakan mengerjakan pekerjaannya dengan semangat kerja yang tinggi. Dari kedua pernyataan tersebut dapat disimpulkan bahwa semangat kerja karyawan PERUM LPPNPI Cabang Tarakan dikategorikan tinggi. Sehingga hubungan antara budaya organisasi dengan semangat kerja dapat dikatakan mempunyai pengaruh positif dan signifikan. Hasil penelitian ini sesuai dengan penelitian terdahulu oleh Jauhari (2015) yang menunjukkan budaya organisasi berpengaruh positif dan signifikan terhadap semangat kerja. Hasil penelitian ini berarti bahwa PERUM LPPNPI dengan budaya organisasi baik, maka semangat kerja karyawannya akan tinggi dalam bekerja yang nantinya akan berdampak pada kinerjanya.
Budaya Organisasi Berpengaruh Positif Signifikan Terhadap Kepuasan $\underline{\text { Kerja }}$

Variabel budaya organisasi berpengaruh positif dan signifikan terhadap kepuasan kerja. Hal tersebut membuktikan bahwajika budaya organisasi baik, maka kepuasan kerja karyawan akan tinggi. Karyawan PERUM LPPNPI Cabang Tarakan dalam bekerja selalu tepat, melakukan analisis, dan mempunyai perhatian yang penuh terhadap pekerjaannya, serta termotivasi untuk selalu inovatif dan berani mengambil resiko dalam bekerja, juga aktivitas organisasional PERUM LPPNPI Cabang Tarakan cenderung menjaga stabilitas kinerja karyawan. Dari ketiga pernyataan tersebut, dapat disimpulkan bahwa budaya organisasi PERUM LPPNPI Cabang Tarakan dapat dikatakan baik. Kemudian dalam hubungannya dengan kepuasan kerja, karyawan PERUM LPPNPI Cabang Tarakan cenderung lebih menyukai pekerjaan-pekerjaan yang memberi kesempatan untuk menggunakan kemampuan dan keterampilan, kebebasan, dan umpan balik mengenai betapa baik mereka bekerja. Dari pernyataan tersebut dapat disimpulkan bahwa kepuasan kerja karyawan PERUM LPPNPI Cabang Tarakan dikategorikan tinggi. Sehingga hubungan antara budaya organisasi dengan kepuasan kerja dapat dikatakan mempunyai pengaruh positif dan signifikan. Hasil ini sesuai dengan penelitian terdahulu oleh Andriani (2014) yang menunjukkan budaya organisasi berpengaruh positif dan signifikan terhadap kepuasan kerja. Hasil penelitian ini membuktikan bahwa PERUM LPPNPI dengan budaya organisasi baik, maka kepuasan 
kerja karyawannya akan tinggi dalam bekerja yang nantinya akan berdampak pada kinerja karyawan.

\section{Kepuasan Kerja Berpengaruh Positif} $\underline{\text { Signifikan Terhadap Semangat Kerja }}$

Variabel kepuasan kerja berpengaruh positif dan signifikan terhadap semangat kerja. Hal tersebut membuktikan bahwa jika kepuasan kerja baik, maka semangat kerja karyawan akan tinggi. karyawan PERUM LPPNPI Cabang Tarakan cenderung lebih menyukai pekerjaanpekerjaan yang memberi kesempatan untuk menggunakan kemampuan dan keterampilan, kebebasan, dan umpan balik mengenai betapa baik mereka bekerja. Dari pernyataan tersebut dapat disimpulkan bahwa kepuasan kerja karyawan PERUM LPPNPI Cabang Tarakan dikategorikan tinggi. Kemudian dalam hubungannya dengan semangat kerja, Lingkungan kerja PERUM LPPNPI Cabang Tarakan mendorong karyawan untuk bekerja lebih baik dan bersikap positif, serta Karyawan PERUM LPPNPI Cabang Tarakan mengerjakan pekerjaannya dengan semangat kerja yang tinggi. Dari kedua pernyataan tersebut dapat disimpulkan bahwa semangat kerja karyawan PERUM LPPNPI Cabang Tarakan dikategorikan tinggi. Sehingga hubungan antara kepuasan kerja dengan semangat kerja dapat dikatakan mempunyai pengaruh positif dan signifikan. Hal tersebut membuktikan bahwa jika kepuasan kerja baik, maka semangat kerja karyawan akan tinggi. Hasil ini sesuai dengan penelitian terdahulu oleh Fahmi (2014) yang menunjukkan kepuasan kerja berpengaruh positif dan signifikan terhadap semangat kerja. Hasil penelitian ini membuktikan bahwa pada PERUM LPPNPI, dengan kepuasan kerja karyawan baik, maka semangat kerja karyawan akan tinggi dalam bekerja yang akan berdampak pada kinerja karyawan.

Budaya Organisasi Berpengaruh Positif Signifikan Terhadap Semangat Kerja dengan Kepuasan Kerja Sebagai Variabel Mediasi

Variabel budaya organisasi berpengaruh positif dan signifikan terhadap semangat kerja dengan kepuasan kerja sebagai variabel mediasi. Hal ini dapat dibuktikan oleh hasil uji hipotesis yang menunjukkan bahwa besarnya korelasi antara budaya organisasi terhadap semangat kerja dengan melihat efek mediasi yang ditimbulkan oleh kepuasan kerja adalah nilai thitung $>$ ttabel. Efek mediasi terlihat dari nilai beta $(\beta)$ ketika terjadi hubungan langsung antara budaya organisasi terhadap semangat kerja pada tabel uji hipotesis. Dari nilai beta ( $\beta$ ) yang bertanda negatif tersebut, mengartikan bahwa tidak ada pengaruh langsung budaya organisasi terhadap semangat kerja. Namun ketika muncul kepuasan kerja sebagai variabel mediasi, maka nilai beta $(\beta)$ positif. Dari nilai beta $(\beta)$ yang bertanda positif tersebut, mengartikan bahwa ada pengaruh budaya organisasi terhadap semangat kerja dimediasi oleh variabel kepuasan kerja. Nilai tersebut membuktikan bahwa budaya organisasi dan semangat kerja karyawan tinggi, apabila dimediasi. Hal ini mengartikan apabila budaya organisasi baik dengan memperhatikan kepuasan kerja karyawannya secara baik, maka semangat kerja karyawan akan tinggi. 
Hasil penelitian ini membuktikan bahwa PERUM LPPNPI dengan budaya organisasi dan kepuasan kerja karyawan baik, maka semangat kerja karyawannya akan tinggi dalam bekerja yang nantinya akan berdampak pada kinerja karyawan. Ada beberapa faktor yang membuat kepuasan kerja karyawan menjadi baik, dalam kasus ini diantaranya karyawan perlu diberi pekerjaan-pekerjaan yang memberi kesempatan untuk menggunakan kemampuan dan keterampilan, kebebasan, dan umpan balik mengenai betapa baik mereka bekerja. Sehingga dapat dikatakan bahwa adanya kebebasan keterampilan atas pekerjaan yang dilakukan oleh karyawan dan reward dalam bentuk motivasi, mampu untuk meningkatkan kepuasan kerja karyawan yang akan berampak positif terhadap semangat kerja karyawan.

\section{KESIMPULAN}

Berdasarkan fenomena,rumusan masalah, hipotesis, metode penelitian yang digunakan, dan hasil penelitian maka peneliti menarik kesimpulan secara empiris bahwa terdapat kovarasi antara struktur kepemilikan dengan keputusan pendanaan pada perusahaan manufaktur. Yang dimana artinya pengungkapan struktur kepemilikan berdampak terhadap keputusan pendanaan pada perusahaan manufaktur.

Berdasarkan hasil penelitian dan pembahasan hasil pengujian hipotesis atas pertanyaan-pertanyaan penelitian maka dapat diambil kesimpulan sebagai berikut :

1. Budaya organisasi berpengaruh positif dan signifikan terhadap semangat kerja karyawan di PERUM Lembaga
Penyelenggaraan Pelayanan Navigasi Penerbangan Indonesia Cabang Tarakan.

2. Budaya organisasi berpengaruh positif dan signifikan terhadap kepuasan kerja karyawan di PERUM Lembaga Penyelenggaraan Pelayanan Navigasi Penerbangan Indonesia Cabang Tarakan.

3. Kepuasan kerja berpengaruh positif dan signifikan terhadap semangat kerja karyawan di PERUM Lembaga Penyelenggaraan Pelayanan Navigasi Penerbangan Indonesia Cabang Tarakan.

4. Budaya organisasi berpengaruh positif dan signifikan terhadap semangat kerja dimediasi oleh kepuasan kerja karyawan di PERUM Lembaga Penyelenggaraan Pelayanan Navigasi Penerbangan Indonesia Cabang Tarakan.

\section{SARAN}

Berdasarkan dari kesimpulan penelitiann ini, maka dapat dikemukakan saran-saran sebagai berikut :

1. Bagi organisasi, diharapkan mampu mempertahankan budaya organisasi yang telah terbina dengan baik, menjaga stabilitas kinerja karyawannya dengan memperhatikan semangat kerja dan kepuasan kerja yang dimiliki oleh karyawannya agar dapat tujuan organisasi dapat tercapai.

2. Bagi penelitian selanjutnya yang akan mengambil judul penelitian yang sama, diharapkan dapat menguji dan mencoba metode berbeda dengan memodifikasi penelitian ini ataupun mencoba menggunakan variabel lain, dan disarankan mengambil obyek 
penelitian berbeda dengan tujuan melihat fenomena berbeda agar membuat penelitian ini berkembang menjadi suatu sumber kajian yang dapat dipercaya dan dijadikan panutan untuk penelitian berikutnya.

\section{DAFTAR PUSTAKA}

Andriani, Rian.(2014). "Pengaruh Budaya Organisasi dan Kompetensi Terhadap Kepuasan Kerja Karyawan Pada Bank Tabungan Negara di Bandung." Ecodemica. Vol II. No. 2September 2014. Universitas BSI, 2014.

Anoraga, Pandji. 2005. Psikologi Kerja. Jakarta : Rineka Cipta.

Arikunto, Suharsimi. 2006. Prosedur Penelitian Suatu Pendekatan Praktek. Jakarta: PT. Rineka Cipta.

Asnawi, Sahlan. (1999) "Semangat Kerja dan Gaya Kepemimpinan". Jurnal Psikologi 1999, No. 2, Universitas Persada Indonesia, 1999: 86-92.

Badriyah, M. 2015. Manajemen Sumber Daya Manusia. Bandung: CV Pustaka Setia.

Damayanti, Fitria.(2015). "Pengaruh Lingkungan Kerja Terhadap Semangat Kerja Melalui Disiplin Kerja."Jurnal Investasi Fakultas Ekonomi Unwir Vol.1, No.1 Januari 2015.

Edison, dkk. 2016.Manajemen Sumber Daya Manusia. Bandung: Alfabeta.

Fahmi, Oktadini Khoirul.2014. Pengaruh Kepuasan Kerja dan Besarnya Gaji Terhadap Semangat Kerja Karyawan Non
Medis RSUD Sunan Kalijaga Kabupaten Demak Tahun 2012/2013. Surakarta: Universitas Muhammadiyah Surakarta.

Failasufah, Fina.2011. Pengaruh Kepuasan Kerja dan Budaya Organisasi Sekolah Terhadap Semangat Kerja Guru di SMA Negeri 1 Pecangaan Jepara. Semarang: Universitas Negeri Semarang.

Ghozali, Imam.2007. Analisis Multivariate Dengan Program SPSS, Cetakan Empat. Semarang: Badan Penerbit Universitas Diponegoro.

Ghozali, Imam.2011. Analisis Multivariate Dengan Program SPSS, Cetakan Delapan. Semarang: Badan Penerbit Universitas Diponegoro.

Gibson, James L., John M. Ivancevich, and Donnelly.2000. Organizations. Boston: McGraw Hill Higher Education.

Greenberg, Jerald, and Robert A. Baron.1997. Behavior In Organizations. New Jersey: Prentice-Hall International, Inc.

Handoko, T. Hani. 2014. Manajemen Personalia dan Sumber Daya Manusia, Edisi Kedua. Yogyakarta: BPFE.

Hasibuan, Malayu S. P.2008. Manajemen Sumber Daya Manusia. Jakarta: PT.Bumi Aksara.

Herawan,dkk (2015). "Pengaruh Buadaya Organisasi Terhadap Kepuasan Kerja Karyawan Studi Pada PT. Bank Rakyat Indonesia (Persero) Kantor Cabang Kota Malang Kawi." Jurnal Administrasi Bisnis 
(JAB) Vol. 1 No. 1 Januari 2015.

Jauhari, Slamet.(2015). "Pengaruh Budaya Organisasi Terhadap Semangat Kerja Pegawai Bagian Umum Sekretariat Daerah Kabupaten Boyolali." Jurnal Manajemen Sumber Daya Manusia Vol. 9 No. 2 Desember 2015. Fakultas Ekonomi Universitas Surakarta, 2015: 181 - 188.

Josiah, Trisnowati. (2011). "Pengaruh Budaya Organisasi, Komitmen dan Kepuasan Terhadap Kinerja Pegawai di Provinsi Lampung (Studi pada Badan Pemberdayaan Masyarakat dan Pemerintahan Desa)." Jurnal Manajemen dan Bisnis Vol.2 No.1 Oktober 2011, 2011: 1629.

Karsini, Patricia Dhiana Paramita, and Maria Magdalena Minarsih. "Pengaruh Semangat Kerja dan Disiplin Kerja Terhadap Kepuasan Kerja Yang Berdampak Pada Kinerja Pegawai Dinas Pengelolaan Keuangan dan Aset Daerah (DPKAD) Kota Semarang." Journal Of Management, Volume 2 No.2 Maret 2016, 2016.

Kreitner, Robert, and Angelo Kinicki.2001. Organizational Behavior. New York: McGrawHill Higher Education.

Luthans, Fred.2006. Perilaku Organisasi, Edisi 10. Yogyakarta: Andi.

Mangkunegara, Anwar.2008. Manajemen Sumber Daya Manusia Perusahaan. Bandung: Remaja Rosdakarya.
Nawawi, H.1990. Administrasi

Personalia untuk Meningkatkan

Produktivitas. Jakarta: CV. Haji

Masagung.

Panggabean, M. S. 2004. Manajemen Sumber Daya Manusia. Bogor: Ghalia Indonesia.

Phegan, Barry.(2017). Company Culture: Tools for Change. 2013.

http://companyculture.com/141 -the-benefits-of-a-good-

organization culturel (accessed November 6, 2017).

Ranupandjojo, H, dan Suad Husnan.2005. Manajemen

Personalia. Yogyakarta: BPFE.

Robbins, Stephen P.2001. Organizational Behavior. New Jersey: Prentice-Hall International, Inc.

Schein, Edgar H.1997. Organizational Culture and Leadership. San Francisco: Jossey-Bass.

Singarimbun, M., and S. Effendi. 1990.

Metode Penelitian Survai.

Jakarta: LP3ES.

Solimun.2010. Analisis Variabel Moderasi dan Mediasi.

Malang: Program Studi Statistika FMIPA-UB.

Sugiyono.2012. Metode Penelitian Administrasi dan $R \& D$. Bandung: Alfabeta.

Sugiyono.2007. Metode Penelitian Bisnis. Bandung: Alfabeta.

Wahyuni, Evi. 2015. "Pengaruh Budaya Organisasi dan Gaya Kepemimpinan Terhadap Kinerja Pegawai Bagian Keuangan Organiasi Sektor Publik dengan Motivasi Kerja Sebagai Variabel Intervening (Studi Kasus Pada Pegawai Pemerintah Kota Tasikmalaya)." Jurnal 
Nominal/Volume IV Nomor

1/Tahun 2015. Universitas

Negeri Yogyakarta.

Wibowo. 2011. Budaya Organisasi:

Sebuah Kebutuhan untuk

Meningkatkan Kinerja Jangka

Panjang. Jakarta: PT. Raja

Grafindo Persada. 
